\title{
An Example of Distortion in Turkish Social Studies and History Textbooks: Slavery
}

\author{
Ayten Kiriş Avaroğulları ${ }^{1}$ \& Muhammet Avaroğulları ${ }^{1, *}$ \\ ${ }^{1}$ School of Education, Muğla Sitkı Koçman University, Muğla, Turkey \\ *Correspondence: School of Education, Muğla Sıtkı Koçman University, 48100, Mentese - Muğla, Turkey. Tel: \\ 90-553-166-4852. E-mail: muhammet@mu.edu.tr
}

Received: November 9, 2018

Accepted: November 24, $2018 \quad$ Online Published: December 17, 2018

doi:10.5430/wje.v8n6p82

URL: https://doi.org/10.5430/wje.v8n6p82

\begin{abstract}
This study focuses on how issues of slavery are discussed in the social studies and history textbooks in Turkey. A total of 16 textbooks were examined. 7 of these books were published by the Ministry of National Education and others by various private publishers. A qualitative research design is adopted and the data were classified according to the themes that emerged during the process of the researchers' familiarity with the subject. The findings show that slavery issues are either distorted or omitted in textbooks. The first one of the distortions and omissions in the textbooks is that slavery is reflected as if it were only experienced in western societies. Secondly, the textbooks present an image that Islam banned slavery and hence, it is implied that slavery did not take place in Turkish history. Another distortion or deficiency is the presentation of slavery as a problem of distant past. Finally, slavery is presented as a situation only black people were subjected. The findings required a two-way discussion. Therefore, firstly, identity issues are discussed within the framework of social identity theory. Finally, suggestions were made on what to do in these and similar situations in the textbooks.
\end{abstract}

Keywords: slavery, social identity theory, history education, social studies education, textbook

\section{Introduction}

As lecturers in a college, we are always amazed at the lack of knowledge displayed by our first grade students concerning some important matters in Turkish history. One of these matters is slavery in Turkish history. The students always seem unaware of the fact that slaves existed in former Turkish societies. They were able to detect slavery in foreign societies but could not do so in Turkish history. The same is true for slavery in Islam. Whenever the question of whether or not Islam permits slavery is raised, the answer given is always no. Intrigued by this phenomenon, we pondered on the reasons behind this ignorance. Thus we decided to investigate students' knowledge about slavery before coming to college and what kind of history is taught in high schools and middle schools.

Actually, slavery has a long past in Turkish history (Parlatır, 1983; Uzun, 1998). According to Parlatır (1983), Turks were familiar with the concept of slavery even before adopting a sedentary life. At the beginning of their history, Turks were settled in central Asia. They had a nomadic life but were neighbors to a great sedentary civilization, China. Parlatır (1083) suggest that this institution was spread to nomadic tribes from China. He notes that some Turks were captured by Chinese in 300 B.C. and sold in slave markets. Additionally, he informs that Turks as early as $3^{\text {rd }}$ century B.C. had slaves of their own who worked in their homes as servants or shepherds in pastures (Parlatır, 1983). It is understood that slavery continued among Turks in the following eras as well. For example, in the Orkhon Inscriptions which are the first examples of a literary Turkish and date back as late as $8^{\text {th }}$ century A. D., slavery is mentioned briefly (Parlatır, 1983). Slavery kept its existence during subsequent times as well. Seljuks and Ottomans who are both seen as precedents of present day Turkey had slaves as well (Parlatır, 1983). After the Turks had converted to Islam, the institution of slavery was strengthened since slavery was endorsed by sharia laws. Eventually during the Ottoman period, it was completely institutionalized and seeped especially into the upper class of the society (Parlatır, 1983). Sak (1992) states that there were slave markets in many Ottoman cities including Istanbul, Bursa, and Edirne which were capital cities of the empire.

In the Ottoman Empire, both the state and individual citizens owned slaves (Pala, 1998). Slaves owned by the state 
were used to work either as soldiers (janissaries) or high bureaucrats of the state. According to Üçok (1993), these slave bureaucrats (grand viziers of the empire etc.) despised the Turkish public which led to the emergence of an idiom called "stupid Turk". Other than the Ottoman Palace, slaves were employed generally by upper class Ottomans and the middle class to some degree (Parlatır (1983). Contrary to the examples observed in the Western world, they were not employed in big farms in general (Tahiroğlu, 2011). Yet, some slaves were placed in certain areas and were expected to engage in agricultural activities on the condition that a certain part of the land was left for them (Tahiroğlu, 2011). This is similar to the serf system seen in the west.

The abolition of slavery in Turkish history was a gradual process which lasted for approximately 60 years. Parlatır (1983) summarizes this process as follows. In 1839, in the Rescript of Gulhane, it was declared that all people are equal and any discrimination would not be accepted. Then in 1846, the closure of slave markets was announced. In 1847, the sultan visited the cabinet during a session and declared a ban on the trade of blacks. In 1855, he banned the slave trade of Cherkess people followed by a re-declaration of the ban on the trade of black people due to the fact that this trade continued in the southern parts of the empire. According to Cevdet Pasha (as cited in Tahiroğlu 2011), this imperial order of 1857 caused a riot in Mecca. Some prominent people in Mecca called for a jihad against Turks who publicly violate holy sharia. In 1890, the Ottoman Empire participated in a Brussels conference where a treaty about prohibition of slavery was signed. From that date on slave markets gradually disappeared. It seems that the last visible evidence of slavery was annihilated when concubines in the palace of Abdulhamid II were taken out of the palace in 1908. Parlatır (1983) notes that some of the girls refused to leave the palace and the life they were used to, but eventually the eviction occurred. According to Tahiroğlu (2011) in 1909, the newly crowned Ottoman sultan, Mehmet V, banned slavery one more time. Slavery was taken off the agenda with the declaration of the republic whose first constitution states that every Turk is born and lives free, and all Turks are equal before the law.

According to Tahiroğlu (2011), slavery was not of any economic importance in the Ottoman Empire because the economic structure of the empire did not depend on slavery. Slaves were not forced to work in the agriculture sector because the Ottoman Empire lacked big farms compared to the Latifundiums of the Roman Empire. Thus, Tahiroğlu (2011) concludes that slavery was not well established in the Ottoman Empire. Yet, it was possible to encounter slaves in every stage of social and economic life.

We would like to add a few words about slavery in Islam as well. According to Yaka (1995) and Uzun (1998), Islam permits slavery. Islam encourages the salvation of slaves; orders slaves to be treated well but İslam does not prohibit slavery (Bagatur, 2011, Yaka, 1995). According to one view, only war prisoners can be enslaved in Islam. Another view on the other hand states that, with some restrictions, people who are born from slave mothers can be enslaved too (Sak, 1992; Tahiroğlu, 2011; Uzun, 1998). It should also be noted that the term war prisoners does not apply to only men who fought in enemy ranks. Women and children of the defeated are considered as prisoners of war as well (Uzun, 1998; Yaka, 1995). Thus they are eligible for enslavement as well.

Despite the clear evidence of slavery in Turkish and Muslim history, students' apparent lack of knowledge intrigued us into investigating what social studies and history textbooks tell about slavery. Textbooks are the most commonly used teaching material by the teacher. Therefore it is crucial that their content and presentation should be up-to date and accurate (Hawkins \& Buckendorf, 2010). As Byrne (2001) puts it, textbooks "construct impressions and illustrations that later become students' explanations, beliefs, and understanding of the world" (p. 299). Since "textbooks serve as ... the criteria that determine truth" (Romanowski, 1994, p. 3) we thought perhaps this is a good starting point to investigate.

We believe that the way slavery is handled in Turkish social studies and history textbooks is worthy of investigation because schools owe students a more complete and correct version of past or historic occurrences. When students don't learn an accurate version of history they lose confidence in what the school teaches, and this loss of confidence makes the students prefer to believe in overt propaganda (Avarogullari and Demir, 2015).

\subsection{Theoretical Framework}

In this study we will investigate whether lack of information about slavery in Turkish social studies and history textbook can be explained by social identity theory. The theory of social identity was developed in 1970's by Henri Tajfel and his graduate student, John Turner (Hoggs, et al., 2004). The purpose of the theory is to explain prejudice, discrimination and inter-group conflict processes beyond individual or interpersonal processes (Hoggs, et al., 2004, Tajfela \& Turner, 1971).

According to Tajfel and Turner (1971), the basic principles of social identity theory are:

1. Individuals seek to obtain a more positive social identity or maintain their positive social identity. 
2. Positive social identity is largely obtained through comparison in favor of the in-group to outgroup: the group to which one belongs should look different and be positively dissociated from other groups.

3. In situations where social identity does not satisfy the individual, the individual tries to either leave his or her own groups and join other prestigious groups or make their groups more positive (p.40).

At the heart of the Social Identity Theory is the concept of social categorization (Turner et al., 1987). People tend to categorize both other people and themselves (Hogg et al., 2004). People identify themselves with the group they belong to and thus acquire a group identity (Demirtas, 2003, Tajfel \& Turner, 1971). The categorization process leads to feelings of love, trust and solidarity towards in-group members (Hoggs, et al., 2004), but also reveals negative feelings and attitudes towards members of out-groups. A process of comparison comes after categorization. This comparison includes a struggle to look better (Turner, 1975; Turner, Brown \& Tajfel, 1979). Belonging to a high-status social group is a way of achieving a more positively perceived personal identity. Because the value of the group identity determines the value of personal identities, people want to raise the status of their group and preserve this high status (Hoggs, et al., 2004). The comparison is never objective; people favor a positive attitude when evaluating their own groups (Hogg, et al., 2004). The struggle to distinguish in-group from out-groups with more positive directions is explained by two concepts in the theory of social identity. These concepts are in-group favoritism and bias (Hogg, et al., 1986; Turner, Brown, \& Tajfel, 1979). Just a sense of belonging to a certain group may be sufficient for people to attribute more positive features to in-groups (Tajfel \& Turner, 1971; Turner, Brown, $\&$ Tajfel, 1979). There is no need for a real conflict of interest for emergence of those feelings (Tajfel, Billig, Bundy \& Flament, 1971; Tajfel \& Turner, 1971). Yet, in the case of real competition even a sense of hostility may appear (Tajfel \& Turner, 1971). Undoubtedly this situation strengthens in-group favoritism and bias. In-group favoritism is accompanied by out-group discrimination (Hogg, et al., 1986, Tajfel, 1982).

\section{Method}

This study is conducted with a content analysis method. All content analysis transforms the descriptive information into categories at a specific point. This can be done in two ways. In the first method, the researcher sets the categories before the research commences. In the second method, the investigator allows the categorization to occur while the analysis process is in progress, after being thoroughly familiar with the collected descriptive data. In this study, categories appeared after the researcher got familiar with the data. There can be many reasons why a researcher would want to carry out content analysis. Here, the purpose was obtaining descriptive information about slavery. The unit of analysis was determined as written expressions and visual images depicting slavery. In Turkey, historical subjects are included in social studies courses in middle schools. In high schools, on the other hand, there is a "history" course. Thus we examined social studies and history textbooks to collect relevant data. Textbooks were downloaded from the website of the Ministry of Education of Turkey. A total of 16 textbooks were used for the analysis and all have been examined in this study. During the data collection process, only open content was considered. Excerpts from textbooks were provided for reliability purposes. Before presenting the data as categories, frequency and percentages per textbook were calculated. Meaningful units of words which contained the word "slave" were counted to calculate the frequency. This unit was often composed of a sentence. Where the word "slave" occurs in close sentences and within the same semantic integrity, the entire passage was accepted as a unit. Pictures were not counted in cases where the word "slavery" was not mentioned in the subtitles. In these cases it was considered as a single unit with subtitles. Additionally, expressions in relation to each category were also presented as frequencies and percentages.

According to the Ministry of National Education (MEB) Course Books and Training Materials regulations (2012) in Turkey, textbooks are written by private publishing companies or people appointed by the Ministry according to the guidelines set by the Ministry of Education. These books are then delivered electronically to the Ministry. A preliminary examination is made by the training and education committee and if it is accepted, the panel examination commences. Panelists consist of teachers or field specialists with at least a doctoral degree. Each panel includes teachers, field experts, visual designers and language experts. The books found appropriate by the panel are printed for five years. It is always the case that books prepared by more than one publisher about the same subject are recommended by the ministry. Then, the Ministry is informed of the book to be used by the school principals. The relevant general directorate of the Ministry buys such books and distributes them to schools free of charge. 


\section{Findings}

The findings indicate that slavery is mentioned in most of the social studies and history textbooks used in Turkey. But there is no independent chapter reserved for teaching slavery. The main reason for this is the fact that there is no theme or benchmark regarding slavery in either social studies or history curricula. Table 1 demonstrates the frequency of instances where slavery is mentioned.

Table 1. Frequency of Slavery in Textbooks

\begin{tabular}{lllll}
\hline & Textbook and publisher & Publisher & Frequency & Percentage \\
\hline 1 & Middle schools Social studies grade 5 textbook & MEB & 1 & 1,47 \\
2 & Elementary schools Social studies grade 5 textbook & Berkay & 0 & 0 \\
3 & Elementary schools Social studies grade 5 textbook & Evren & 0 & 0 \\
4 & Elementary schools Social studies grade 5 textbook & Harf & 1 & 1,47 \\
5 & Elementary schools Social studies grade 5 textbook & MEB & 0 & 0 \\
6 & Elementary schools Social studies grade 6 textbook & Evren & 10 & 14,70 \\
7 & Elementary schools Social studies grade 6 textbook & MEB & 0 & 0 \\
8 & Elementary schools Social studies grade 6 textbook & Yakınçag & 3 & 4,41 \\
9 & Elementary schools Social studies grade 7 textbook & Evren & 3 & 4,41 \\
10 & Elementary schools Social studies grade 7 textbook & Tuna & 0 & 0 \\
11 & Elementary schools Social studies grade 7 textbook & Ekoyay & 0 & 0 \\
12 & Elementary schools Social studies grade 7 textbook & MEB & 1 & 1,47 \\
13 & Secondary schools history grade 9 textbook & MEB & 28 & 41,17 \\
14 & Secondary schools history grade 10 textbook & Tuna & 1 & 1,47 \\
15 & Secondary schools history grade 11 textbook & MEB & 2 & 2,94 \\
16 & Elective Islam History & MEB & 18 & 26,47 \\
& & Total & 68 & 99,98 \\
\hline
\end{tabular}

An examination of the textbooks revealed some patterns regarding the handling and presentation of slavery in history. First of all, slavery is presented as something belonging to foreign cultures, particularly the Western world. Secondly and similar to the first, slavery is presented as something sustained by religions other than Islam. The textbooks maintain the idea that İslam is strictly against slavery and imply that slavery is banned by İslam. Thirdly, according to the textbooks Turks can be enslaved but they do not enslave other nations. Fourthly, the textbooks suggest generally that slavery is a thing of the past and has no connection whatsoever with the present world. Lastly, the textbooks suggest that only blacks were enslaved. These findings will be presented below in details.

\subsection{Westerners as Slave Owners}

Slavery is mentioned in the textbooks 68 times with 26 times being related to the western societies, which corresponds to $38.23 \%$ of total mentions. In addition, slavery is mentioned 4 times with references to the European Human Rights Convention and United Nations Universal Declaration of Human Rights which implies that slavery is a major problem in Western societies.

According to the textbooks, slavery in western societies began in the early ages and continued to increase until more recent times. It began with Ancient Greece and Rome, continued in mediaeval ages and intensified with the discovery of the Americas. Some excerpts from the sixth grade textbook of Evren Publishing (Karabiyik, 2014) are as follows.

In the year 300, 400 thousand people out of Athens' 500 thousand population were captives. Considering that women and slaves did not participate in the administration, it seems that these two groups did not enter into the concept of people (p. 139).

On page 143, there is a picture depicting slavery. In the picture, while slaves are carrying loads, western-style people are giving orders to them. The text next to the picture is as follows:

From the Early and Middle Ages to the late 19th Century, people were used as slaves. They were bought and sold like goods or commodities (p. 143).

In a question on page 153 of the book, filling the gap in the sentence is required. The correct answer is "slave". 
In the Middle Ages ... trade was being done in Europe

The book implies that the problem of slavery in the Western world was solved just recently.

In the United States, slavery was abolished in the 19th century. The process of having equal rights for black people continued for many years(p. 143).

The idea that slavery is inherent to the Western world repeats itself in the $7^{\text {th }}$ grade as well. In the $7^{\text {th }}$ grade social studies textbook of Evren publishing (Karabiyık, 2010), slavery is mentioned three times and all are related with the west. One of the passages is presented below:

In ancient Greek and Roman periods, economic relations were entirely based on agriculture and production was done through slaves.

What can you say about the features of this era? (p. 105).

Another social studies textbook published by the Ministry of Education for the $7^{\text {th }}$ grade (Comission, 2016) refers to slavery only once. There is a picture depicting slaves working on a cotton farm and the text accompanying it is as follows.

In the above photo, of a field in North America, slaves working for cotton, an important raw material for the English weaving industry, are seen. What could contribute to the UK economy of cotton growing in North America? Please explain (p. 128).

A history textbook for grade 9 published by the Ministry of National Education (MEB) (Kapar et. al., 2017) has many passages that connect slavery to Western societies as well. Sample passages from this textbook are presented below.

Slavery is an intrinsic part of western history.

Historical developments that determine the beginning and end of the Old and New Ages, especially the Middle Ages, are events directly related to the history of Europe. While these periods are created, slavery, feudalism, and capitalism, which illustrate the historical development stages of Western societies, are taken into consideration (p. 21).

Slavery starts in Rome,

Roman society is divided into three classes: patricians, plebes and slaves...The slaves, who were brought from the countries under Roman occupation, were the class who worked as servants in the houses of the patricians and as workers in the farms(p.75).

And continues through the middle ages:

The social order in Western and Middle Europe where the seigneur has political, economic, legal and military rights and constructed on the basis of land slavery is called "feudalism".

A history textbook for grade 10 published by Tuna (Tüysüz, 2017, p.65) provides another example of western attitudes towards slavery and slaves:

During the discoveries by removing the Aztec, Maya and Inca civilizations from America, the colonial European states confiscated the riches of these civilizations. They enslaved the indigenous people. On the other hand they carried the people they captured from Africa to their colonies to work on the fields and mines.

Another instance of how the western world is characterized with slavery can be found in excerpts from the Elective Islam History textbook (Aydın, et. al., 2014). In the passage below while westerners are portrayed as enslavers, Muslims are depicted as emancipators.

Jews: When Muslims conquered Andalusia, there were also Jews. Muslims returned all rights to this group, which had been enslaved by the Visigoths (p.86).

A few pages later, how cruel the westerners were is recalled again:

When Christians occupied the city of Malaga this time in 1487, they captured almost fifteen thousand Muslims in the city. A hundred of these were sent to the Pope, sixty young girls were sent as gifts to the king of Portugal and Italy, while the rest were distributed as slaves to Christian families, churches, soldiers and royal officials (p. 93). 
In the following pages, the textbook continues to make references to slavery in the context of the transatlantic slave trade.

\subsection{Islam is against Slavery}

Another theme in the textbooks is that Islam is against slavery. Actually, slavery is mentioned 17 times in connection with Muslims or Muslim societies. This number equals to $25 \%$ of the total mention of slavery. An analysis of these mentions reveals that in eight of them, it is categorically stated that Islam abolished slavery or ordered slaves to be treated well, while expressions are neutral in the remaining nine occasions. Although it is not stated verbally, the textbooks give a strong message by implying that Islam abolished slavery. As an example, the sixth grade textbook of Evren Publishing (Karabıyı, 2014. p. 68) includes the following statements:

There was no political unity in Arabia before Islam. Arabs lived in tribes. There was bloodshed between the tribes. People worshiped idols. There were class differences between them. Slavery was common. This period is called the Days of Ignorance.

It is clear that these expressions give a negative meaning to slavery. However, they also suggest that slavery had been abolished after the coming of Islam, and it is not quite true as discussed below. The $9^{\text {th }}$ grade history textbook of secondary education (Kapar at al., 2017. p. 144) has similar expressions as well.

People in pre-Islamic Arabia were divided into three social classes: free people, freedman and slaves. The main element of the tribe, the free people, had all rights. Slaves and concubines (women slaves) who do not have any rights could be bought and sold, inherited, and employed in everyday work.

By saying "pre-Islamic", a false perception has been created as though this situation has changed after Islam. However, slavery continued after Islam. On the same page, students are asked to write an essay on Islam's view of slavery. With this assignment we think that the intention is for the above perception to be strengthened.

On the other hand, the statements on the other pages of the book indicate that slavery continues after Islam. For example, the farewell message of the prophet Muhammad is given on page 153. In this farewell sermon, the Prophet Muhammad speaks of slaves twice. Likewise, there are references to the existence of slaves in Islamic societies in the following pages of the book. However, there is no discussion of this situation in keeping up with the negative attitude of Islam towards slavery. There is no record in the books about how slaves were enslaved. Slavery in Islamic society is treated as given. The presence of slaves is reflected in a sterile manner, almost as a technical detail.

The textbook which most used the concepts of slavery and Islam together is the course book of Selective Islamic History (Aydınlı et al., 2014). This book explains the Arab society before Islam as follows (p.20).

The people of the tribes came from the free people, freedman and the slaves. The freemen who were the main members of the Tribe (Sayyid, master, non-slave) were the ones who had a common lineage. Slaves and concubines were bought and sold at fairgrounds, inherited as commodities, working in agriculture, commerce and other service jobs.

Here, the impression that the situation changes after Islam is being created. On page 27 of the same textbook, it is clearly stated that Islam opposes slavery:

In Mecca, the administration was in the hands of rich and powerful people. Slavery and slave trade were common. Islam opposed slavery and accepted that all people were free from birth. This situation was a deterioration of social structure according to the polytheists. The Makkah idolaters reacted to our Prophet because he considered that the slave and the master were equal.

According to the textbook, As well as not enslaving other people, Islam saved slaves from the hands of the Europeans (p.86):

When the Muslims conquered Andalus, there were also Jews. To this group, which was introduced by the Visigoths into the slave state, Muslims returned all their rights.

However, on the $103^{\text {rd }}$ page of the same book, there are expressions about the insurrection of slaves:

The Negro Movement emerged in and around Basra, with social and economic reasons among internal problems. Many black slaves working in the farms and salt fields in this area complained about the weight of the working conditions and revolted under the leadership of a person named Ali bin Muhammad who claimed that he was from the lineage of the Ali.

After these statements, a debate could be expected as to how these people are slaves, despite the prohibition of slavery in Islam. However, the textbook does not mention this topic at all. Apart from this, other pages also have 
expressions about the existence of slaves in Islamic societies, but there is no statement or discussion about the contradiction created by this situation.

\subsection{Turks Can Be Enslaved But Do Not Enslave}

As noted earlier, slavery is treated as if it never existed in Turkish societies. Turkish speaking societies and slavery are mentioned together only 6 times. While in 4 of these cases, the Turks are depicted as slaves, there are only 2 references to the fact that a Turkish speaking society might be having slaves. One of them can be found in Middle schools history textbook for the grade 9 (Kapar et al., 2017) published by the Ministry of National Education (MEB). The reference is as follows: "The slaves who joined themselves from the army of Ghaznevids drowned in benevolence" (p.191) by the Seljuk. As a note, we should remember that both sides are considered as Turkish speaking societies by the current Turkish historical community. The second is in the Middle school's history textbook for grade 11 (Sever, et al., 2017) where it is stated that among the documents remaining from Uyghur period there were documents about slave sales. Aside from these examples, there is no reference to the literature we had discussed in the introduction of this study.

\subsection{Slavery is Something of a Distant Memory}

In the textbooks, slavery is treated as a thing of the past, an institution that disappeared completely. Slavery is mentioned 64 times with a reference to a historical era. Slavery in the antiquity is mentioned 21 times which corresponds to $33 \%$. Slavery in the middle ages is referenced 29 times which corresponds to $45 \%$. Finally, slavery after the reformation age, it is mentioned only four times which makes $6 \%$ of the total references to slavery. There is no mention of people who are still slaves or who are forced into slavery under different names in the present day. According to the textbooks, slavery was experienced in the ancient and middle ages and then it died out. Slavery is also mentioned as an experience that should have to be experienced during the development of civilization. When talking about slavery, human and moral dimensions are ignored and a sterile tone is employed as if it is a technical subject. Some citations on this topic will be presented below.

In the middle school history textbook for grade 9 (Kaparet al., 2017) published by Ministry of National Education (MEB), it is stated that "slavery, which is a common institution in the majority of ancient societies, has continued its existence for thousands of years" (p.21). Here, emphasizing that slavery is included in all societies the situation has been normalized in addition to being reflected as an institution of ancient societies i.e. slavery is a thing of distant past. Though, in the same page, slavery was said to be unacceptable in terms of human rights today, it is also stated that old societies should be evaluated with their own values. Thus an opportunity was missed on behalf of students' making some moral inferences. Evaluating societies with their own merits can be accepted in terms of history, but it is not very valuable in terms of education if it does not lead to students making moral inferences.

The same textbook (Kapar et al., 2017) presents slavery as an inevitable part of human development process:

"Slavery has been brought about by mankind's adopting a sedentary life and by the development of agrarian communities based on human labor. More people are needed to feed the growing population in these communities. In order to meet this labor, those who were enslaved were used in agricultural work." (s.84)

An elementary school social studies textbook for grade 7 (Karabıyık, 2010) goes one step further and depicts slaves as a part of a machine:

"The first crane picture is seen in a book written by the Roman architect Vitruvius in the 10th century BC. This crane consisted of a pole with a spool on top and fixed with ropes. It was tied to a load via another rope that goes around a roller and it was lifted by the foot mill pushed by the slaves" (s.84).

No discussion has been made about the fallacy of a man being forced to act like a machine.

According to the textbooks, slavery was experienced in ancient Greece, Mesopotamia, Anatolia in ancient times; then it became prevalent in the western World in the middle ages and especially in times after the discovery of the Americas. The problem of slavery seems to have been solved somehow in the $20^{\text {th }}$ century.

This view is maintained by the $6^{\text {th }}$ grade textbook of primary school social studies (Karabiylk, 2014) published by the Evren publishing house, stating the problem was solved by the European Human Rights Convention on 4th November 1950. However the textbook reminds the reader that the Ottoman Constitution, which predates the convention, had an article stating that "all Ottomans have personal freedoms. They are responsible for not preventing the freedom of others". Thus, it is implied to the students that the problem of slavery has been removed much earlier in our society. The $6^{\text {th }}$ grade textbook of primary school social studies (Tekten, 2015) repeats the same view as well. 
Kaparat al. (2017) gives reference to the $4^{\text {th }}$ article of Universal Declaration of Human Rights about the removal of slavery.

\subsection{Only Blacks Were Slaves}

Another misrepresentation of slavery can be found in the implication that only black people were enslaved throughout the history. We have to note that this is not articulated verbally in the textbooks, yet overemphasis on the transatlantic slave trade causes such a misunderstanding. There are two images about slavery in the textbooks and both are in line with this misconception. The image in elementary schools social studies textbook for grade 6 (Karabıyık, 2014) by Evren publishing portrays black slaves unloading a ship in a seaport. Next to the slaves there are people dressed in the European style. The image reinforces two stereotypes at the same time: western people are slave owners and slaves are blacks. The second image can be found in elementary schools social studies textbook for grade 7 (Commission, 2016) published by Ministry of National Education (MEB). The image demonstrates black slaves picking cotton. Next to the cotton fields there are white people well dressed and watching over them. Under the picture is the write-up that slaves in cotton fields in North America are picking cotton for British textile industry. Just as the aforementioned image, this image fosters the same stereotype as well: Westerners are slave owners and blacks are slaves.

\section{Discussions}

In this chapter, we will discuss the five patterns observed among the findings, followed by a discussion about the emergence of these patterns.

The first pattern indicates that the textbooks handle slavery as a problem that happened mainly in the West. The problem here is not the depiction of slavery in the West but the textbooks' implication that the western societies were mere slave owners or insinuating that while slavery in the other parts of the world is sporadic, it was systematic in the West. This is a distorted depiction of the history.

Atrocities committed by westerns towards slaves and how they institutionalized slavery are exemplified abundantly. Yet there is no mention of how slaves were treated in the Islamic world, especially in the Ottoman past of Turks. This omission implies that there was no slavery in our past, or slaves in our history were quite happy. While there are details about how Christians enslaved Muslims as exemplified by Aydın et. al. (2014), there is no detail about how Muslims got their own slaves.

Another omission in the textbooks is the contribution of western societies to the abolition of slavery. Actually there is abundant information about this matter even in Turkish literature. For example, Engin (1998) notes that the British were effective in banning the slave trade in the Ottoman Empire. According to Şen (2007), the real effect on the abolition of slavery came from the West. At the beginning of the 19th century, a strong anti-slavery movement began in Europe and in America. In particular, England was the champion for the abolition of slavery. Britain was putting diplomatic pressure over the Ottoman Empire, especially to remove the African-based slavery. The slave markets in Istanbul were closed because they dented the Ottoman image in Europe. With the agreements made with Britain, the British inspected the ships in the Ottoman territorial waters, reported the wrong practices they witnessed to the Ottoman administration, prepared reports on this subject and created a constant pressure on the Ottoman state. With the influence of political developments, the Ottoman state, which wanted to take into account the European public opinion, had to show a positive attitude towards the desire to abolish the slavery. Other than Britain, states such as France and Italy were effective too. However, it seems that the British Ottoman treaty of 1880 was a turning point in this process. With this agreement, England gained a wide authority over the slave trade in the Ottoman state and exercised this authority. Another turning point was the Brussels Declaration, which was attended by important European states in 1890. Within the later period, slavery in the Ottoman Empire completely disappeared. Since the purpose of this study is not to give an historic account of how slavery was abolished in the Ottoman Empire, we will end this discussion here with a last remark from Erdem (2004, p.91): "The Ottoman government took the majority of measures against the slave trade as a result of British diplomatic initiatives." For a more detailed discussion of the subject one may look at Şen (2007) and Erdem (2004). The main point here is the fact that the textbooks failed to highlight the western contribution towards the abolition of slavery in the world, and in Turkey. Yet they are very quick to label westerns as the sole originators and executors of slavery.

The second pattern implies that Islam banned slavery. But, what is the reality? There are many references to slavery in the Qur'an. For example, the $4^{\text {th }}$ verse of the surah of Muhammad (47) states that: 
"Therefore, when you meet the disbelievers in the battle-field, first smite their necks. Then, when you have crushed them completely, bind the prisoners tight. After that (you have the choice) whether you show them favor or accept ransom, until the war lays down its arms".

Apart from this, some of the surah and the verses mentioned in slavery are as follows: Al-Azhab (33/50), Al-Baqara (2/177, 221), Al-Balad (90/13), Al-Ma'ida (5/89),Al-Mujadila (58/3), An-Nisa' (4/3, 24, 25, 36, 92), An-Nur (24/31, 32, 33,58), Ar-Rum (30/28) At-Tawba (9/60). In some of these verses, there are orders to treat slaves well, but a ban of slavery is not asked in any of them. The existence of these verses shows that slavery in Islam is legitimate. Further details about the place of slavery in Islam will not be given as it is not one of the aims of this research, but it has also been expressed in other studies that slavery is considered legitimate by Islam (Bagatur, 2011; Birsin, 2012, Engin, 1998; Yaka, 1995).

No textbook gives place to the fact that slavery is considered legitimate in Islam. The verses that commanded the well-treatment of slaves and encouraged emancipation of slaves were brought to the forefront, and created a false impression that Islamic societies were free of slavery; however, as reminded by Şen (2007), the attempts of the Ottoman state to ban slavery were met by violent resistance from the Hijaz region on the religious grounds.

Thirdly, according to the textbooks it is possible to suggest that the Turks have no connection what so ever with slavery. Yet references about Turks being enslaved can be found. For example according to a statement in an elementary schools social studies textbook for grade 6 (Tekten, 2015) published by Yakınçağ: "When the enemies saw the Köktürks, they immediately returned, the Köktürks were unaware, the Köktürks were defeated. The elders were all slaughtered, the minors were enslaved" (p.64). In another instance, Turks are defined as "Without a state, without a sovereign, enslaved Turkish people" in a Middle schools history textbook for grade 11 (Sever, et al., 2017) published by Ministry of National Education (MEB). Another excerpt can be found in the Selective Islam History (Aydinlı et. al, 2014). It states that "It is highly probable that the prophet faced ... Turkish merchants coming to Basra and Bahrain, Turkish-born prisoners and Turkish-born slaves" (p.117). Although it is not stated clearly, the message of the textbooks is that Turks might be forced into slavery but they do not enslave people of other nations, which is completely wrong as demonstrated in earlier parts.

As a fourth pattern, the textbooks treat slavery as fait accompli. It has been abolished by European Human Rights Convention and Universal Declaration of Human Rights. It is a naive approach to imply that the problem of slavery can be removed with some articles of agreements. Not to remind students that some stages of the anti-slavery process that began in Europe at the beginning of the 19th century included bloody incidents such as the American Civil War means depriving them of many opportunities for their own moral development. This understanding can prevent students from making an effort to solve real problems because they are being solved somehow. Moreover, such an understanding will appear to lessen the contribution of men and women who sacrificed a lot for the abolition of slavery.

Furthermore, the problem of slavery has not been annihilated presently. According to a report published by International Labor Organization (2016), 40.3 million people suffered from slavery as of 2016 and in the last five years a total of 89 million people experienced some form of slavery. The report states that slavery occurs across the globe, slaves can be females or males, and they can be forced to work in various sectors. Students might be receiving goods and services that are produced by slaves and might be completely unaware of it due to the false image that slavery no longer exists in the present day.

Finally, the fifth pattern indicates that only black people were enslaved. However people from every race were enslaved throughout the history. According to Sak (1992, p. 218), percentages of slaves in terms of ethnic origin as reflected in the court records are as follows: Abkhazian 0.4\%, Persian 4.26\%, Albanian 0.04\%, Barbary 0.04\%, Romanian (Eflaki and Bogdani in the original text) 1.54\%, Bosnian 0.04\%, Bulgarian 0.08\%, Cherkes 1.85\%, European (Efrenci in the original text) $0.35 \%$, Armenian $0.21 \%$, Frank 0.04\%, Georgian 8.48\%, Abyssinian 1.67\%, Croat $0.52 \%$, Indian 0.08\%, Polish 1.5\%, Hungarian 2.29\%, Morean 0.04\%, Muscovite 1.06\%, Austrian 0.31\%, Greek 0.18\%, Russian 20.12\%, Serfi (?) 0.62\%, Tuti (?) $0.13 \%$, Wallach $0.08 \%$ and Black $11.47 \%$. We should keep in mind that this report is based on the data collected from six provinces of Ottoman Empire. However we believe that it gives an idea about the general distribution of slaves in terms of ethnicity. This report demonstrated that black slaves were not even the biggest slave group in Ottoman Empire. They were second after Russians. It is interesting to note that other people are classified by nationality but blacks appear to be a generic term for people from many countries. This may be because the Ottomans saw the white slaves as more valuable. So they may have kept more detailed records about them. Parlatır (1983) reports that Arab and black slaves were employed for the most tedious chores in the house. Alternatively, it can be argued that the Ottomans did not realize that Blacks were of different 
nations. Black slaves were brought to the country through slave traders. The Ottomans naturally did not wonder about the origins of these people from distant countries they did not know. According to Sak (1992), on the other hand, the first reason for the abundancy of Russian slaves is the fact that, historically, Russian countries were slave exporting countries. And the second reason is the fact that there were frequent wars between Ottomans and Russians which resulted in many prisoners of war.

How can we explain the emergence of these patterns? We believe that the findings of this study require at least a two faceted discussion about: identity issues and moral issues.

\subsection{Identity Issues}

In the textbooks, it is understood that distortions and omissions have been made in addressing the subject of slavery. Attempt has been made to fully omit the act of slavery in Turkish and Muslim history, and distortions have come to the fore where it cannot be done. How can we explain the distortions and omissions of the "other" in the history textbooks of many different countries (Abdou, 2017; Council on Interracial Books for Children, 1977; Grever \& Vlies, 2017; Lathan, 2013; Loewen, 1990; Mehlinger, 1981; Podeh, 2002; Sewall, 2003; Wolf, 1992; Zhao \& Hoge, 2006)

One of the most plausible answers to this question might be that educational policies require it.If we look at the case of history education in Turkey, "identity" has been an important part of the educational policies regarding history education since the proclamation of the Republic of Turkey. The idea of identity based history education was dominant, especially in the early periods (Çiçek, 2012; Dede, 2017; Yıldırım and Şimşek, 2017), it continues to be effective (Aktekin, 2009; Dinç, 2011) and is still effective (Vurgun, 2016). In Turkey, the curriculum is determined by the Ministry of National Education centrally, and "identity" is one of its marked features. That the authors of the textbooks are influenced by the emphasis on the identity in the curriculum is natural to some extent. Different expressions in different books, however, prove that authors of textbooks are at liberty, though it is not unlimited, in the way they deal with the subject. But the authors of textbooks, perhaps because of their historiographical stand, because of their identity or perhaps because of the fear of not meeting the ministerial expectations, failed to have an objective attitude towards slavery.

A second explanation of the distortions and omissions statement, which in our view includes the first explanation, could be the theory of social identity. According to Lorenz (2008), one of the main purposes of history education is "nation building". History textbooks written for such purposes may contain distorted information about the past (Berger, 2007) or information may be partially or completely omitted (Abdou, 2017). It is understood that the textbooks in Turkey have been written for the purpose of identity formation to a great extent, as demonstrated by the fact that they imply that slavery had never been experienced in Turkish history and Islam abolished slavery. Barton and Levstik (2004) stated that one of the aims of history teaching was identity formation. According to them, teaching important events in national history "can create a sense of group membership and allegiance"(Barton \& Levstik, 2004, p. 45). However, they also point out that the use of history to create identity has some drawbacks. One of these reservations is the danger that: "identification always entail exclusion"(Barton and Levstik, 2004, p.46). There are other researchers who point out that history can be used to create identity. Such as Harris and Burn (2016) who note that the history curriculum has very important role in terms of "how individuals and groups perceive themselves and others" (p.518). The words such as "sense of group membership", "exclusion", "themselves" and "others" immediately attracts attention. These words bring to mind the social identity theory which is briefly mentioned above.

Social identity is the identity that individuals get from the social groups they belong to. It seems that authors of the textbooks, and curriculum makers to some extent, see Turks and Muslims as social groups and identify themselves with those groups. Logically, they want a better social identity and attribute better features to their groups. Tajfel and Turner (1971) suggest several ways of achieving it. One of the suggestions made is comparing the in-group to the out-group on "a new dimension". Findings of this study bring to mind that relatively backward appearance of Turkish society or Muslim societies in comparison to the West requires a new dimension for comparison. It seems that this new dimension is slavery, because the visibility of slavery in history is, thanks to western media, so clear that it is quite attractive to make a comparison and obtain a more positive social identity.

Social identity theory also expresses that there is no need for a real conflict of interest for the emergence of those in-group bias and out-group discrimination (Tajfel, Billig, Bundy, \& Flament, 1971; Tajfel \& Turner, 1971). However, a sense of hostility appears among the members of the losing group towards the winning group in a real competition, because the losing group is deprived of sources and social identity is damaged (Tajfel \& Turner, 1971). A quick review of historical accounts provides evidence in this way as well. Turks and Muslims have been losing 
against the West for centuries in almost every field you can think of. These losses deprive them from not only a positive social identity but also real sources as well. Thus, it is natural that a sense of hostility may grow against the West which demonstrates itself as out-group discrimination.

\subsection{Moral issues}

In addition, the results of the research show that the subject of slavery is addressed without any connection with the present day. According to Barton and Levstik (2004), one of the reasons for teaching history is the "moral response". Accordingly, if the students are expected to be active citizens of a pluralistic and democratic society, they should respond morally to historical events. The idea of Moral response echoes in the benchmarks of historical thinking of Seixas (2006) as well. According to Seixas (2006), there must be a "moral dimension" of historical thinking. However, according to the findings, the textbooks seem to neglect this too. The fact that slavery in its present dimension has not been included at all is a great omission. Even when slavery in the past is told, no opportunities have been created for students to make personal connections. However, the history curriculum in Turkey gives includes historical thinking skills, thus allowing history teaching to be structured to make moral judgments possible (Ministry of National Education, 2018). Here it is worth remembering the question of Romanowski, who complains about the fact that the information in the history books is handled as separated from a "moral component" and presented as technical information (1994): "Can students break into our democratic ideals by studying textbooks that deny the existence of justice and equality or by memorizing historical events portraying injustices?" (p. 26). The answer is of course no. Similarly, in some history textbooks, which Morgan (2010) has also examined, it has been determined that topics are written as technical texts free from moral accents. Their findings show great similarity to the style of textbooks in Turkey. It is possible, however, to produce textbooks that can bring moral dimension to the agenda (Morgan, 2010). Besides slavery being a problem that continues to be relevant as mentioned above, it is also possible to make connections to the different problems of today, such as discrimination or racism (Klein, 2017).

\section{Conclusion}

The discussion above brings us inevitably to make inferences about the content of the textbooks. We believe that textbooks are obliged to provide students with "accurate" and "complete" information. Yet we also acknowledge that every textbook requires selection in terms of content. It is inevitable to omit some subjects since it is impossible to give place to everything that happened in the past. But we also believe that textbook writers are under a moral obligation to make their selection for the best interest of the students. They should always be careful not to indoctrinate students. Additionally, a distorted version of history is unacceptable under any condition. Presenting a distorted version of the facts is much more harmful to the students than omitting a subject completely. A textbook that has distortion means treachery to the students who read it. As Morgan (2010) points out, "textbooks do matter very much because they bear immutable authority, together with the teacher, on the pupils/young readers for whom they are written (p.301). Textbooks are the gathering place of "correct" and "valid" information (Olson, 1980). Textbooks are an authority for students to trust (Wineburg, 2001). This authority is so great that students make "few judgements about their biases, trustworthiness, historical context or perspectives" (Paxton, 1999, p. 333). Textbooks are "transcendental source" of knowledge (Olson, 1980, p. 192). According to Harris and Reynolds (2014), "content is incredibly important, and decisions about what to omit are just as important as decisions about what to include in history curriculum" (p.466). If the textbooks are so important for the pupils, providing accurate and complete information to the pupils is a moral responsibility for the authors of the textbooks. However, the textbooks in this study could not provide this because they were too focused on identity creation, and textbook authors were too much influenced by their social identities instead of providing accurate and complete information, they distorted or omitted some factual knowledge they saw as a threat to their national identity

As a result, it is understood that slavery related contents in the history and social studies textbooks contain significant distortions and omissions. The enslavement of people is considered as a negative situation, but those who do it are often portrayed as westerners, slavery in Turkish and Islamic history is omitted or tolerated. In the textbooks, distorting or omitting information about the past will prevent students from participating in a democratic society in a healthy way. It will prevent students from having healthy discussions about the society they live in or the global society in general. This situation may lead to appearance of prejudice or even hostile behaviors in the students towards the other nations. Additionally, the existence of slavery in Turkish history is not something that should embarrass Turkish students. It should be faced and responded to morally of course. Instead of concealing slavery, we can remind students how slavery in Turkey was abolished peacefully, and teach students to celebrate it. 
Lastly, from now on textbook publishers and educational policy makers should focus on discovering the omissions or distortions made by other subjects in textbooks and concentrate on how to solve this problem. Perhaps looking for the best practices of authors who have coped with this problem might be a good point to start.

\section{References}

Abdou, E. D. (2017). Copts in Egyptian history textbooks: towards an integrated framework for analyzing minority representations. Journal of curriculum studies, 50(4), 476-507. https://doi.org/10.1080/00220272.2017.1398352

Aktan, H. (2010). Hz. Peygamber döneminde kölelik olgusu ve insan özgürlüğüne Kur'anî yaklaşım [The concept of slavery during the prophet and the Qur'anic approach to human freedom]. Atatürk Üniversitesi Ilahiyat Fakültesi Dergisi, 0(16), 59-79

Aktekin, S. (2009). Türkiye'de tarih eğitimi [History education in Turkey]. In S. Aktekin, P. Harnett, M. Öztürk, D. Smart (Eds.), Çok kültürlü bir Avrupa için tarih ve sosyal bilgiler öğretimi [History and social studies teaching for a multicultural Europe] (pp. 27-44). Ankara: Harf Eğitim

Avaroğulları, M., \& Demir, M. A. (2015). Uncritical receivers of historical myths: a grim picture from Turkish high schoolers. US-China Education Review, 5(4), 270-277.

Bagatur, S. (2011). Osmanlıda kölelik [Slavery in Ottoman Empire].(Unpublished master's thesis). Kırıkkale/Social Sciences Institute, Kırıkkale.

Barton, K.C., \& Levstik, L.S. (2004). Teaching history for the common good. Mahwah, NJ: Lawrence Erlbaum.

Birsin, M. T. (2012). İslam Devletler hukukunda savaş esirlerine uygulanan yaptırımların analizi [The analysis of the legal sanctions for the prisoners of war in Islamic law]. Hitit Üniversitesi Ilahiyat Fakültesi Dergisi, 11(21), 163-194.

Byrne, M. M. (2001). Uncovering racial bias in nursing fundamentals textbooks. Nursing And Health Care Perspectives, 22(6), 299-303.

Council on Interracial Books for Children, I. N. (1977). Stereotypes, Distortions and Omissions in U.S. History Textbooks. New York.

Çiçek, M. T. (2012). Erken cumhuriyet dönemi ders kitapları çerçevesinde Türk ulus kimliği inşası ve "Arap ihaneti" [Turkish Nation-Building and the "Arab Treason" in the Context of Textbooks in the Early-Republican Period]. İstanbul: Bilim ve Sanat Vakfi.

Dede, K. (2017). Erken cumhuriyet döneminde ulus inşası ve tarihî romanlar: savaşçı, medeni ve millî kahraman [Nation building and historiccal novels in the early republican period: warrior, civilized and national hero]. Kebikec: İnsan Bilimleri İ̧̧in Kaynak Araştırmaları Dergisi, 44, 91-112.

Demirtaş, H. A. (2003). Sosyal kimlik kuramı, temel kavram ve varsayımlar [The Social Identity Theory, Essential Concepts and Assumptions]. Iletiş̧im Araştırmaları, 1(1), 123-144.

Dinç, E. (2011). Eski ve yeni ortaöğretim tarih programının amaç ve içerik özelliklerinin karşılaştırmalı olarak incelenmesi, [A Comparative Investigation of the Previous and New Secondary History Curriculum: The Issues of the Definition of the Aims and Objectives and the Selection of Curriculum Content]. Kuram ve Uygulamada Eğitim Bilimleri, 11(4), 2135-2148.

Engin, N. (1998). Osmanl devletinde kölelik [Slavery in Ottoman state].İstanbul: Marmara Üniversitesi İlahiyat Vakfi Yayınları.

Erdem, H. (2004). Osmanlı'da köleliğin sonu 1800-1809 [The end of slavery in the Ottoman Empire 1800-1809]. İstanbul: Kitap yayınevi.

Grever, M., \& van der Vlies, T. (2017). Why national narratives are perpetuated: A literature review on new insights from history textbook research. London Review of Education, 15(2), 286-301. https://doi.org/110.18546/LRE.15.2.11

Harris, R., \& Burn, K. (2016). English history teachers' views on what substantive content young people should be taught. Journal of curriculum studies, 48(4), 518-546. https://doi.org/10.1080/00220272.2015.1122091

Harris, R., \& Reynolds, R. (2014). The history curriculum and its personal connection to students from minority ethnic backgrounds, Journal of Curriculum studies, 46(4), 464-486. https://doi.org/10.1080/00220272.2014.881925 
Hawkins, J. M., \&Buckendorf, M. (2010). A current analysis of the treatment of Japanese Americans and internment in United States history textbooks. Journal of International Social Studies, 1(1), 34-42.

Hogg, M.A., Abrams, D., Otten, S., \& Hinkle, S. (2004). The social identity perspective intergroup relations, self-conception, and small groups. Small Group Research, 35(3), 246-276. https://doi.org/10.1177/1046496404263424

Hogg, M.A., Turner, J. C., Nascimento-Schulze, C., \& Spriggs, D. (1986). Social categorization, intergroup behaviour and self-esteem: two experiments. Revista de Psicologia Social, 1(1), 23-37. https://doi.org/10.1080/00933104.2016.1213677

Klein, S. (2017). Preparing to teach a slavery past: history teachers and educators as navigators of historical distance, Theory \& Research in Social Education, 45(1), 75-109.

Lathan, J. L. (2013). New Format, Same Old Story?: An Analysis of Traditional and Digital U.S. History Textbook Accounts of Slavery. ProQuest LLC. ProQuest LLC. Retrieved from http://search.ebscohost.com/login.aspx?direct=true\&db=eric\&AN=ED553792\&lang=tr\&site=eds-live

Mehlinger, H. D. (1981). The United States as portrayed in geography and history textbooks in the USSR. Social Education, 45(4), 234-38.

Ministry of National Education (MEB) (2018). Orta ögrretim tarih dersi (9, 10 ve 11. sinıflar) ögretim programı [Secondary Education History Course (9, 10 and 11th Grades) Curriculum]. Ankara. Retrieved from http://mufredat.meb.gov.tr/ProgramDetay.aspx?PID=344

Ministry of National Education (MEB) (2012). Course books and training materials regulations. 12/9/2012 28409.

Morgan, K (2010). Scholarly and values-driven objectives in two South African school history textbooks: an analysis of topics of race and racism. Historical Social Research, 35(3), 299-322. http://dx.doi.org/10.12759/hsr.35.2010.3.299-322

Olson, D. R. (1980). On the language and authority of textbooks. Journal of communication, 30(1), 186-196. https://doi.org/10.1111/j.1460-2466.1980.tb01786.x

Parlatır, İ. (1983). Türk sosyal hayatında kölelik [Slavery in Turkish social life]. Belleten, XLVII(187), 805-829.

Paxton, R. J. (1999). A deafening silence: history textbooks and the students who read them. Review of Educational Research, 69(3), 315-339. https://doi.org/10.3102/00346543069003315

Podeh, E. (2002). The Arab-Israeli conflict in Israeli history textbooks, 1948-2000. Westport, CT: Greenwood Publishing Group.

Romanowski, M. (1994). Fleeing from democratic ideals: The content of U.S. history textbooks. Paper presented at the Annual Meeting of the Association for Supervision and Curriculum Development (Chicago, IL, March 19-22, 1994).

Sak, İ. (1992). Şer'iye sicillerine göre sosyal ve ekonomik hayatta köleler (17. ve 18. yüzyllar) [According to Sharia registers, slaves in the social and economic life (17th and 18th centuries)] (Unpublished master's thesis). Selçuk University/Social Sciences Institute, Konya.

Seixas, P. (2006). Benchmarks of historical thinking: A framework for assessment in Canada. The Center for the Study of Historical Consciousness. Retrieved 15 Mart 2018'de alındığıyer from http://historicalthinking.ca/sites/default/files/files/docs/Framework_EN.pdf

Sewall, Gilbert T. (2003). Islam and the textbooks: A report of the American textbook council. New York: American Textbook Council.

Sumner, W. G. (1906). Folkways: A study of the sociological importance of usages, manners, customs, mores, and morals. Boston, MA: Ginn and Company.

Şen, Ö. (2007).Osmanlı'da köle olmak [Being a slave in the Ottoman Empire]. İstanbul: Kapı yayınları.

Tahiroğlu, B. (2011). Osmanlı imparatorluğunda kölelik [Slavery in Ottoman empire]. İstanbul Üniversitesi Hukuk Fakültesi Mecmuası, 45(1-4), 649-676.

Tajfel, H., \& Turner J.C. (1971). An integrative theory of intergroup conflict. In W. G. Austin and S.Worchel (Eds.), The social psychology of intergroup relations (pp. 33-47). Monterey, California: Brooks/Cole Pub. Co.

Tajfel, H., Billig, M.G., Bundy, R.P., \& Flament C. (1971). Social categorization and intergroup behavior. Europesn 
Journal of Social Psychology, 1(2), 149-178. https://doi.org/10.1002/ejsp.2420010202

Tajfel, H. (1982). Social psychology of intergroup relations. Annual Review of Psychology, 33(1), 1-39. https://doi.org/10.1146/annurev.ps.33.020182.000245

Turner, J. C., Brown, R. J., \& Tajfel H. (1979). Social comparison and group interest in in group favouritism. European Journal of Social Psychology, 9(2), 187-204. https://doi.org/10.1002/ejsp.2420090207

Turner, J.C. (1975). Social comparison and social identity. European Journal of Social Psychology, 1(5), 5-34.

Turner, J.C., Hogg, M.A., Oakes, P.J., Reicher, S.D., \& Wetherel, M.S. (1987). Rediscovering the social group: a self-categorization theory. Oxford, England: Blackwell.

Uzun, E. (1998). IV. yüzyllda Osmanlı toplumunda kölelik [Slavery in Ottoman society in IV century](Unpublished master's thesis). Gazi University/Social Sciences Institute, Ankara.

Vurgun, A. (2016). Milli tarih nedir? [What is national history?]. İstanbul: Yeni İnsan Yayınevi.

Wineburg, S. (2001) Historical thinking and other unnatural acts: charting the future of teaching the past. Philadelphia: temple University Press.

Wolf, A. (1992). Minorities in U.S. history textbooks, 1945-1985. Clearing House, 65(5), 291. https://doi.org/10.1080/00098655.1992.10114228

Yaka, Z. (1995). İslamda kölelik [Slavery in Islam]. (Unpublished master's thesis). Selçuk University/Social Sciences Institute, Konya.

Yıldırım, T., \& Şimşek, A. (2017). Erken cumhuriyet dönemi'nde "biz"in inşası: tarih ders kitapları üzerine bir değerlendirme ["We" construction at early republic period: an assessment about history textbooks]. Gazi University Journal of Gazi Educational Faculty (GUJGEF), 37(1), 367-389.

Zhao, Y., \& Hoge, J. D. (2006). Countering textbook distortion: war atrocities in Asia, 1937-1945. Social Education, 70(7), 424-430. 